Universidad de Lima

Facultad de Derecho

Carrera de Derecho

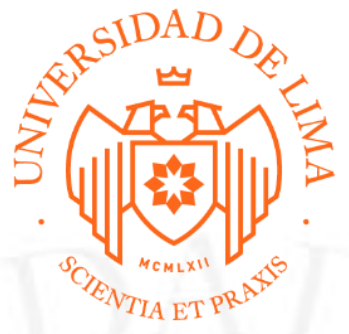

\title{
CIVIL: "RESOLUCIÓN DE CONTRATO" Y ADMINISTRATIVO: "COMPETENCIA DESLEAL"
}

Trabajo de suficiencia profesional para optar el Título Profesional de Abogado

\author{
Alejandro Arturo Zorrilla de la Cuba
}

Código 20133291

$$
\text { Lima - Perú }
$$

Setiembre de 2019 


\title{
CIVIL: "RESOLUCIÓN DE CONTRATO"
}

Materia: Resolución de contrato

Nro. de Expediente: DE-CONTRA0031 (23482-2010-0-1801-JR-CI-13)

\begin{abstract}
RESUMEN
El expediente materia de sustentación versa sobre un contrato de compraventa vehicular celebrado entre dos personas naturales. De manera posterior a la celebración del contrato y la correspondiente tradición del bien, el comprador decide demandar la resolución del contrato y el pago de una indemnización por daños y perjuicios, debido a la supuesta existencia de un vicio oculto en el motor del vehículo adquirido. La discusión principal se centra en si los desperfectos del vehículo son susceptibles de calificar como vicios ocultos, atendiendo a la normativa aplicable.
\end{abstract}

\section{ADMINISTRATIVO: "COMPETENCIA DESLEAL"}

Materia: Competencia desleal

Nro. de Expediente: DE-INDEC0497

\section{RESUMEN}

El expediente materia de sustentación versa sobre una compañía publicitaria difundida en diversos medios de comunicación por una empresa del sector telecomunicaciones, la cual concurre en el mercado particular de televisión paga. Así, otra empresa del sector denuncia la campaña por la presunta comisión de actos de competencia desleal, en la modalidad de actos de comparación indebida. De manera posterior, la empresa denunciante formula una segunda denuncia por la presunta comisión de actos de denigración en un nuevo comercial de la misma compaña publicitaria. Siendo ello así, la controversia se centra en si la campaña publicitaria tiene o no naturaleza comparativa, así como en la observancia de los requisitos de licitud de la "exceptio veritatis". 